\title{
An unexpected alliance between stress responses to drive oncogenesis
}

\author{
Melissa M Keenan ${ }^{1,2 \dagger}$, Chien-Kuang Cornelia Ding ${ }^{1,2+}$ and Jen-Tsan Chi ${ }^{12^{*}}$
}

\begin{tabular}{|l|} 
Abstract \\
XBP1 is a well-characterized regulator of the unfolding \\
protein response that is activated in response to \\
unfolded or misfolded proteins or nutrient deprivation. \\
The conventional wisdom is that XBP1 is activated \\
to coordinate the unfolded protein response and \\
promote cellular survival under stresses. A recent study \\
provides intriguing evidence that, in triple-negative \\
breast cancer, XBP1 plays a major role in promoting \\
oncogenesis and cancer stem cell properties. \\
Unexpectedly, XBP1 accomplishes this by recruiting \\
hypoxia-inducible factor 1a and activating oncogenic \\
transcriptional programs. This study reveals a \\
surprising hierarchy and alliance between two stress \\
regulators with distinct transcriptional outputs to \\
promote an aggressive oncogenic state.
\end{tabular}

\section{Background}

Cells within a solid tumor are constantly exposed to fluctuating physical and chemical conditions in the microenvironment, including $\mathrm{pH}$ dysregulation, oxidative stress, and nutrient deprivation [1]. To cope with these fluctuations, tumor cells demonstrate a wide spectrum of mechanisms that sense and respond to these stresses. For example, a low partial pressure of oxygen $\left(\mathrm{pO}_{2}\right)$ level stabilizes the hypoxia-inducible factors (HIFs) and triggers a hypoxia response [2]. Similarly, various oxidative stresses promote the nuclear translocation of NRF2 to induce a set of genes that enhances oxidative-stress tolerance. Although these responses facilitate stress adaptations, many of these proteins and pathways also play an active role in promoting or repressing oncogenesis. For example, the

\footnotetext{
* Correspondence: jentsan.chi@duke.edu

${ }^{\dagger}$ Equal contributors

'Department of Molecular Genetics and Microbiology, Duke University Medical Center, 268 CARL Building, Research Drive, Box 3054 DUMC,

Durham, NC 27710, USA

${ }^{2}$ Center for Genomic and Computational Biology, Duke Medical Center, 2177A CIEMAS Building, 101 Research Drive, DUMC 3382, Durham, NC 27708,
} USA

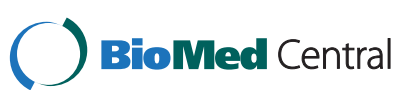

(c) 2014 Keenan et al.; licensee BioMed Central Ltd. The licensee has exclusive rights to distribute this article, in any medium, for 6 months following its publication. After this time, the article is available under the terms of the Creative Commons Attribution License (http://creativecommons.org/licenses/by/4.0), which permits unrestricted use, distribution, and reproduction in any medium, provided the original work is properly credited. The Creative Commons Public Domain Dedication waiver (http://creativecommons. org/publicdomain/zero/1.0/) applies to the data made available in this article, unless otherwise stated.

\section{The article}

In a recent letter to Nature, Chen and colleagues [8] provided intriguing data to show that $X B P 1$ acts as a tumor driver that is required for oncogenesis and cancer stem cell phenotypes associated with TNBC. Unexpectedly, XBP1 mediates its oncogenic properties by physically interacting with and recruiting HIF- $1 \alpha$ to initiate the hypoxia response. The recruitment is essential to induce oncogenic and self-renewal phenotypes in TNBC. An $X B P 1$ gene expression signature identified by using ChiPseq analysis significantly overlaps with the HIF- $1 \alpha$ signature and is associated with poor prognosis in TNBC. Most importantly, epistasis analysis indicates that XBP1 lies upstream of HIF- $1 \alpha$, occupying the regulatory regions and recruiting HIF-1 $\alpha$, via direct physical interaction, to the promoter regions of their shared target genes. Therefore, 
$X B P 1$ is required for a robust hypoxia expression program in TNBC. The authors conclude from these results that that $X B P 1$ s activation and promoter occupancy is not just a passive adaptive response for survival under stress, but rather is a driving oncogenic event in TNBC.

\section{The viewpoint}

This article provides a potential explanation for the elevated hypoxia pathway activation in TNBC and breast cancer stem cells. Moreover, although both HIF-1 $\alpha$ and $X B P 1$ are stress-responsive proteins, high baseline activities of both transcriptional factors can be found in TNBC without apparent stress exposure. What triggers the IRE1XBP1 pathway in TNBC and breast cancer stem cells? One obvious candidate is hypoxia since it activates both $X B P 1$ and HIF-1 $\alpha$. However, the $\mathrm{pO}_{2}$ concentration needed to activate the UPR is much lower $\left(\mathrm{pO}_{2}<0.01 \%\right)$ than what is needed to activate HIF-1 $\alpha$ [9]. Furthermore, whereas hypoxia can be readily triggered by low $\mathrm{pO}_{2}$, $X B P 1$ is activated only by combined low $\mathrm{pO}_{2}$ and lactic acidosis [10]. Therefore, XBP1 may be activated by combined metabolic stresses associated with the acquisition of cancer stem cell and TNBC properties. The higher UPR in TNBC is shown by a dilated ER [8] and increased sensitivity to hsp90 inhibitors that kill cells by hindering the UPR [11]. Such a high level of UPR in TNBC may be caused by increased protein production, higher oxidative stress, or lower levels of nutrients driven by vigorous glycolysis and altered glutamine metabolism [12]. Currently, TNBC is treated primarily by cytotoxic chemotherapies. Targeting the IRE1-XBP1 pathway, such as with an inhibitor of IRE1 (for example, STF-083010) [13], may have significant therapeutic value for TNBC.

Of course, these results also raise questions for further investigation. For example, why does the co-occupancy of XBP1 and HIF- $1 \alpha$ occur in TNBC but not luminal breast cancer cells? Such differences may be explained by TNBC-specific chromatin accessibility status or other available co-activator proteins. Specifically in TNBC, $X B P 1$ may serve as a 'pioneer factor' [14] that recruits other co-activators to trigger and maintain HIF- $1 \alpha$ stability. A recent study has identified at least seven different subtypes of TNBCs with varying sensitivity to hsp90 inhibitors [15]. Therefore, it will be important to determine the extent of this XBP1-HIF-1 $\alpha$ co-regulation among the subsets of TNBCs as well as cancer stem cells from other tumor types.

In conclusion, this study shows an unexpected dominant role for $X B P 1$ in the recruitment and activation of HIF- $1 \alpha$-driven oncogenesis in TNBCs. Like many other stress response pathways, these proteins are not just passive players to keep tumors alive under stress. Instead, stress response proteins can be oncogenic drivers that coordinate stress tolerance with other transcriptional factors to enhance and modulate their expression programs. Therefore, proteins such as HIF-1 $\alpha$ and IRE1XBP1 may be excellent targets in our efforts to treat cancers that have yet to benefit from other targeted therapeutics.

\section{Abbreviations}

ER: Endoplasmic reticulum; HIF: Hypoxia-inducible factor; $\mathrm{pO}_{2}$ : partial pressure of oxygen; TNBC: Triple-negative breast cancer; UPR: Unfolding protein response; XBP1s: spliced XBP1.

\section{Competing interests}

The authors declare that they have no competing interests.

\section{Acknowledgments}

We appreciate the support of the National Institutes of Health (CA125618 and CA106520) and the US Department of Defense (W81XWH-12-1-0148) and comments from Jeffrey Marks.

Published online: 06 November 2014

\section{References}

1. Gatenby RA, Gillies RJ: A microenvironmental model of carcinogenesis. Nat Rev Cancer 2008, 8:56-61.

2. Majmundar AJ, Wong WJ, Simon MC: Hypoxia-inducible factors and the response to hypoxic stress. Mol Cell 2010, 40:294-309.

3. Semenza GL: HIF-1 and human disease: one highly involved factor. Genes Dev 2000, 14:1983-1991.

4. Sporn MB, Liby KT: NRF2 and cancer: the good, the bad and the importance of context. Nat Rev Cancer 2012, 12:564-571.

5. Gatza ML, Kung HN, Blackwell KL, Dewhirst MW, Marks JR, Chi JT: Analysis of tumor environmental response and oncogenic pathway activation identifies distinct basal and luminal features in HER2-related breast tumor subtypes. Breast Cancer Res 2011, 13:R62.

6. Hetz C, Martinon F, Rodriguez D, Glimcher LH: The unfolded protein response: integrating stress signals through the stress sensor IRE1alpha. Physiol Rev 2011, 91:1219-1243.

7. Romero-Ramirez L, Cao H, Nelson D, Hammond E, Lee AH, Yoshida H, Mori K, Glimcher LH, Denko NC, Giaccia AJ, Le QT, Koong AC: XBP1 is essential for survival under hypoxic conditions and is required for tumor growth. Cancer Res 2004, 64:59435947.

8. Chen X, Iliopoulos D, Zhang Q, Tang Q, Greenblatt MB, Hatziapostolou M, Lim E, Tam WL, Ni M, Chen Y, Mai J, Shen H, Hu DZ, Adoro S, Hu B, Song M, Tan C, Landis MD, Ferrari M, Shin SJ, Brown M, Chang JC, Liu XS, Glimcher $\mathrm{LH}$ : XBP1 promotes triple-negative breast cancer by controlling the HIF1alpha pathway. Nature 2014, 508:103-107.

9. Rzymski T, Milani M, Pike L, Buffa F, Mellor HR, Winchester L, Pires I, Hammond E, Ragoussis I, Harris AL: Regulation of autophagy by ATF4 in response to severe hypoxia. Oncogene 2010, 29:4424-4435.

10. Tang X, Lucas JE, Chen JL, LaMonte G, Wu J, Wang MC, Koumenis C, Chi JT: Functional interaction between responses to lactic acidosis and hypoxia regulates genomic transcriptional outputs. Cancer Res 2012, 72:491-502.

11. Caldas-Lopes E, Cerchietti L, Ahn JH, Clement CC, Robles Al, Rodina A, Moulick K, Taldone T, Gozman A, Guo Y, Wu N, de Stanchina E, White J, Gross SS, Ma Y, Varticovski L, Melnick A, Chiosis G: Hsp90 inhibitor PU-H71, a multimodal inhibitor of malignancy, induces complete responses in triple-negative breast cancer models. Proc Natl Acad Sci U S A 2009, 106:8368-8373.

12. Terunuma A, Putluri N, Mishra P, Mathé EA, Dorsey TH, Yi M, Wallace TA, Issaq HJ, Zhou M, Killian JK, Stevenson HS, Karoly ED, Chan K, Samanta S, Prieto D, Hsu TY, Kurley SJ, Putluri V, Sonavane R, Edelman DC, Wulff J, Starks AM, Yang Y, Kittles RA, Yfantis HG, Lee DH, loffe OB, Schiff R, Stephens RM, Meltzer PS, et al: MYC-driven accumulation of 2-hydroxyglutarate is associated with breast cancer prognosis. J Clin Invest 2014, 124:398-412.

13. Papandreou I, Denko NC, Olson M, Van Melckebeke H, Lust S, Tam A, Solow-Cordero DE, Bouley DM, Offner F, Niwa M, Koong AC: Identification of an Ire1alpha endonuclease specific inhibitor with cytotoxic activity against human multiple myeloma. Blood 2011, 117:1311-1314. 
14. Zaret KS, Carroll JS: Pioneer transcription factors: establishing competence for gene expression. Genes Dev 2011, 25:2227-2241.

15. Lehmann BD, Bauer JA, Chen $X$, Sanders ME, Chakravarthy AB, Shyr $Y$, Pietenpol JA: Identification of human triple-negative breast cancer subtypes and preclinical models for selection of targeted therapies. J Clin Invest 2011, 121:2750-2767.

doi:10.1186/s13058-014-0471-1

Cite this article as: Keenan et al:: An unexpected alliance between stress responses to drive oncogenesis. Breast Cancer Research 2014 16:471. 